\title{
Factors Affecting Firms' Performance: The Case of Vietnam construction firms
}

\author{
Nga Ngo Thi Thanh* Duong Phan Thuy Hang Dang Thu \\ University of Transport Technology, 54 Trieu Khuc Street, Ha Noi, Viet Nam
}

\begin{abstract}
In the context of Vietnam's international economic integration, improving the performance of enterprises is increasingly important because it not only affects businesses but also affects the development prospects of the economy. The purpose of the paper is to consider the impact of factors on the performance of listed construction companies in the period of 2012-2018. By means of an empirical analysis, this study uses Eviews econometric software and table data techniques. This study found the factors that positively impact on performance are asset structure, capital structure and firm size that negatively impact the performance of Vietnam listed construction firms. These findings support business administrators in selecting appropriate business and production plans to increase the operating performance of businesses in the construction industry.
\end{abstract}

Keywords: Profitability, construction firms

DOI: $10.7176 / \mathrm{RJFA} / 11-2-15$

Publication date: January $31^{\text {st }} 2020$

\section{Introduction}

In the context of Vietnam's international economic integration, improving the performance of enterprises is increasingly important because it not only affects businesses but also affects the development prospects of the economy.

The global economic crisis has strongly affected the Vietnamese economy, causing all businesses to face many difficulties. And so do the construction industry. Vietnam construction industry has experienced the difficult time in 2009-2013. In the period of 2000-2009, the growth rate of construction industry was $9.6 \% /$ year and in the period of 2009-2013 reached 4.6\% / year. In fact, many businesses have gone bankrupt, one of the reasons is the factors affecting the operational efficiency, which have not been taken seriously in the operation process of enterprises.

Therefore, it is necessary to study the impact of factors on the performance of enterprises. The paper includes 4 main contents: (1) Overview of the impact of factors on firm performance, (2) Research methodology, (3) Empirical results on the impact of factors to the performance of listed construction enterprises, (4) Some recommendations.

\section{Review of related literature}

There are plenty studies about the impact of factors on the performance of businesses in general. Performance is often determined by the return on total assets (ROA), such as Sivathaasan et al. (2013) conducted a research on factors affecting profitability of all manufacturing companies listed on the exchange for the period 2008 - 2012; Khidmat and Rehman (2014) studied 9 chemical companies listed on the Pakistan Stock Exchange for the period 2001 - 2009; Bolek and Wiliński (2012) pointed out the impact of internal and external economic factors on the profitability of all construction companies listed on Warsaw Stock Exchange for the period $2000-$ 2010 ;

Previous studies have considered many factors affecting the performance of enterprises such as capital structure, receivables management, solvency, asset structure, firm size, growth rate.

\section{The capital structure of enterprises}

The capital structure of enterprises is measured by debt-to-assets ratio. The research by Sivathaasan et al (2013) shows that capital structure has a positive effect on firm's performance. Khidmat and Rehman (2014) point out that capital structure has a negative impact on firm performance. The research of Bolek and Wiliński (2012), and the research of Lazaridis and Tryfonidis (2006) (which used data from 131 Greek listed companies for period of $2001-2004)$ also have the same results with the research of Khidmat and Rehman (2014). 


\section{Receivables management}

Receivables management: The level of receivables management is measured through the average collection period. Research by Bolek and Wiliński (2012) suggests that the average collection period has a negative impact on the firm performance. Consistent with this research result, there are other studies: Gill et al. (2010) studied 88 companies listed on the New York Stock Exchange for the period of 2005 - 2007; Napompech (2012) sampled 255 companies listed on Thailand Stock Exchange for the period of 2007 - 2009; Addae and Nyarko-Baasi (2013) studied 125 listed companies on Ghana Stock Exchange for the period of 2004 -2009; Owolabi et al. (2012) studied processing enterprises listed on the Nigerian stock market in the period 2005-2009.

\section{Solvency}

Solvency: Solvency is the ability of a company to meet its long-term debts and financial obligations. Research by Khidmat and Rehman (2014) suggested that liquidity is a positive impact on ROA. While the study of Bolek and Wiliński (2012) suggested that the quick ratio has an opposite effect on ROA.

\section{Asset structure}

Asset structure: Asset structure is expressed by asset structure ratios (fixed asset ratio, current asset ratio). Sivathaasan et al. (2013) argues that asset structure has no effect on ROA. Bolek and Wiliński (2012) showed that asset structure has a negative impact on ROA.

Firm size

Firm size: firm size is expressed through the natural logarithm of the total assets. Sivathaasan et al. (2013) have demonstrated a positive relationship between firm size and performance. Similar results were shown by an empirical research of Bolek and Wiliński (2012). However, the research by Ramasamy (2005) about the oil and gas industry in Malaysia concluded that firm size has a negative impact on firm performance. The reason for this conclusion is that the bigger the size of an enterprise, the more difficult it is to manage and run the business. Moreover, the enterprise has to invest a lot not only for assets but also for other resources such as people. So the profitability ratio of the business per one asset is reduced.

Growth rate

Growth rate: A high revenue growth rate will increase the profit of the business, leading to an increase in performance. A study of Yazdanfar (2013) on Swedish SME companies and Vijayakumar (2011) on Indian automobile trading companies shows that revenue growth has a positive impact on firm performance. These results are consistent with the research results of Bolek and Wiliński (2012).

In the above studies, mainly referring to the factors that affect firm performance of all listed companies, very few studies mention the factors affecting firm performance of enterprises in a certain industry, especially studies in Vietnam. Each sector has its own characteristics, factors affecting firm performance so need to be studied separately so that we can see the impact of factors on firm performance of different sector. Specifically, construction firms have very specific characteristics such as single products, large value of construction works, extensive working area. Moreover, construction firms also need a long time to change the scale and products, so they need to mobilize massive business resources.

\section{Research methodology}

Based on related reviews, the research model is constructed as follows (Figure 1):

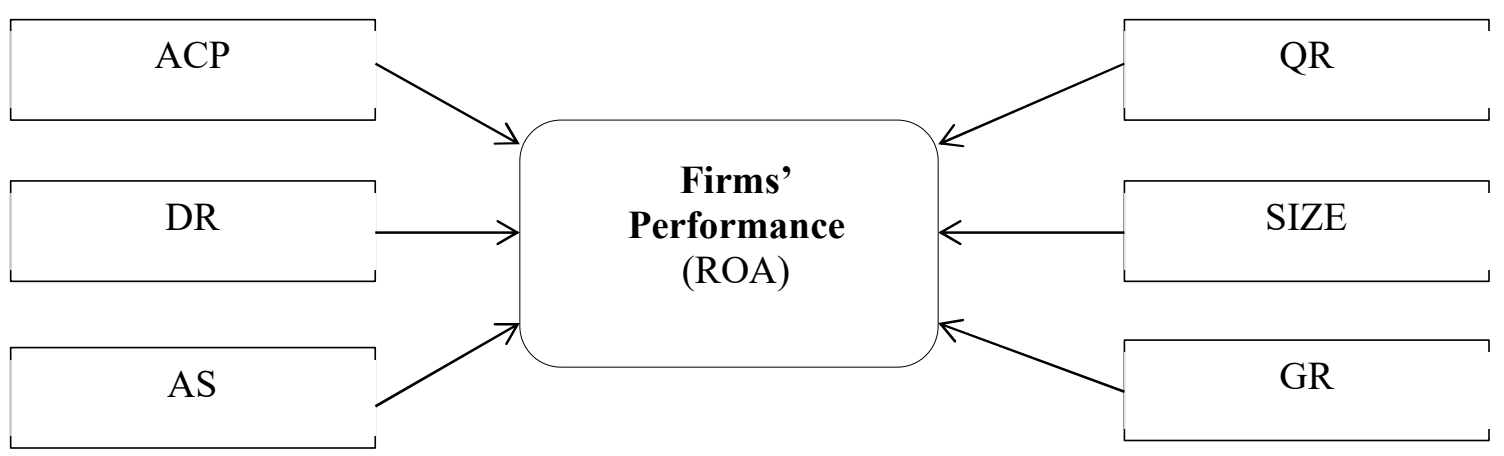

Figure 1. Research model of factors affecting firms' performance 
Table 1. Variables in the research model

\begin{tabular}{|c|c|c|}
\hline Variables & Code & Measures \\
\hline Firms' performance & ROA & $\mathrm{ROA}=$ Net income $/$ Average total assets \\
\hline Average cover period & $\mathrm{ACP}$ & $=360 *$ receivables $/$ net sales \\
\hline Debt ratio & DR & Total liabilities/total assets \\
\hline Asset Structure & AS & Current asset/total assets \\
\hline Quick Ratio & QR & (Current assets - inventory)/ current liabilities \\
\hline Firm size & SIZE & Firm size measured by log of total assets \\
\hline Sale Growth & GR & $\begin{array}{l}\text { (Current period net sales - previous period net sales)/ } \\
\text { previous period net sales }\end{array}$ \\
\hline
\end{tabular}

\section{Research data}

The study relied on secondary data extracted from the audited financial statement of the selected companies. Data of these 40 companies is collected from 2012 to 2018. Audit Financial Statements of these companies will be acquired from the Hanoi stock exchange Library, Ho Chi Minh stock exchange Library, and websites of these companies listed on the Vietnam stock market.

In the study, panel data regression models were employed to examine the determinants constructions companies' profitability in Vietnam. The panel data regression models were the Fixed effects model (FEM). Variables in the research model are shown in Table 1.

\section{Analysis findings and discussions}

Research results

Table 2. Descriptive statistic

\begin{tabular}{llllllll}
\hline & ROA & ACP & DR & AS & QR & SIZE & GR \\
\hline Mean & 0.021421 & 1125.615 & 0.773051 & 0.794036 & 0.960996 & 0.083444 & 69.62950 \\
Median & 0.013000 & 139.0000 & 0.808450 & 0.850000 & 0.739000 & 0.083334 & 1.975000 \\
Maximum & 0.235000 & 100540.0 & 1.045400 & 1.000000 & 9.437000 & 0.094045 & 13797.00 \\
Minimum & -0.156000 & 1.010000 & 0.218200 & 0.120000 & 0.164000 & 0.075609 & -100.0000 \\
Std. Dev. & 0.037988 & 8591.307 & 0.139159 & 0.164275 & 1.033721 & 0.003238 & 839.9360 \\
Skewness & 1.062606 & 9.978437 & -1.255221 & -1.728839 & 5.270493 & 0.388975 & 15.77095 \\
Kurtosis & 11.67858 & 105.0126 & 4.855821 & 6.562846 & 35.03241 & 3.729683 & 256.9250 \\
Jarque-Bera & 931.3997 & 126056.5 & 113.7079 & 287.5765 & 13267.19 & 13.27250 & 763849.3 \\
Probability & 0.000000 & 0.000000 & 0.000000 & 0.000000 & 0.000000 & 0.001312 & 0.000000 \\
Sum & 5.998000 & 315172.2 & 216.4542 & 222.3300 & 269.0790 & 23.36444 & 19496.26 \\
Sum Sq. Dev. & 0.402628 & $2.06 \mathrm{E}+10$ & 5.402888 & 7.529140 & 298.1335 & 0.002925 & $1.97 \mathrm{E}+08$ \\
Observations & 280 & 280 & 280 & 280 & 280 & 280 & 280
\end{tabular}

Note. The descriptive statistic for the study presented in table1 was for constructions company for period of seven years covering 2012 to 2018. Statistical data (Table 2) show the mean value of ROA was 0.021421 of which the highest ROA was 0.235 and the lowest ROA was -0.156 . Average collection period was 1125.61 and quick ratio was 0.960996 current assets over current liabilitiesof firms. 
Table 3. Correlation matrix

\begin{tabular}{lllllll}
\hline & ACP & DR & AS & QR & SIZE & GR \\
\hline ACP & 1 & 0.1604 & 0.0516 & 0.0970 & -0.0502 & -0.0125 \\
DR & 0.1604 & 1 & 0.1016 & 0.0009 & -0.0953 & 0.0565 \\
AS & 0.0516 & 0.1016 & 1 & -0.1181 & 0.4169 & 0.0600 \\
LIQ & 0.0970 & 0.0009 & -0.1181 & 1 & -0.2013 & 0.0239 \\
SIZE & -0.0502 & -0.0956 & 0.4169 & -0.2013 & 1 & 0.0219 \\
GR & -0.0125 & 0.0565 & 0.0600 & 0.0239 & 0.0219 & 1
\end{tabular}

Note. The following Table 3 shows the correlation coefficients between variables. The purpose is to examine whether there is close correlation between independent variables and dependent variables to exclude variable that may lead to multi-collinearity. This is necessary step before running the regression. The results show that the correlation coefficient between any pair independent variables in the model is no less than 0.8 and therefore multicollinearity is unlikely to occur.

Table 4. Model summary

\begin{tabular}{ll}
\hline Indicators & Coefficients \\
\hline R-squared & 0.630506 \\
Adjusted R-squared & 0.547856 \\
S.E. of regression & 0.025544 \\
F-statistic & 7.628640 \\
Prob(F-statistic) & 0.000000 \\
Durbin-Watson stat & 1.417533
\end{tabular}

Note. R-square value was found to be 0.630506 . This implies that the combined effects of Profitability was found to be negatively correlated with average cover period, debt ratio, asset structure, quick ratio, firm size and sale growth explained $63.05 \%$ of the variation in the profitability of constructions companies while the remaining $36.95 \%$ was due to the other variables not captured in this study. F- value indicates that the model used in the study is significant ( $\mathrm{prob}>\mathrm{F}=0.0000$ ).

Table 5. Regression Results

\begin{tabular}{lllll}
\hline Variable & Coefficient & Std. Error & t-Statistic & Prob. \\
\hline C & 1.027112 & 0.204397 & 5.025093 & 0.0000 \\
ACP & $-1.69 \mathrm{E}-07$ & $2.67 \mathrm{E}-07$ & -0.633969 & 0.5267 \\
DR & -0.279063 & 0.030392 & -9.182095 & 0.0000 \\
AS & 0.092118 & 0.021504 & 4.283791 & 0.0000 \\
QR & -0.003338 & 0.002458 & -1.357815 & 0.1759 \\
SIZE & -10.30468 & 2.232357 & -4.616056 & 0.0000 \\
GR & $2.30 \mathrm{E}-06$ & $2.18 \mathrm{E}-06$ & 1.055036 & 0.2925
\end{tabular}

Note.

Results regarding the impact of firm size on the performance of listed constructions companies confirm the findings of previous studies conducted in Greece (i.e. Notta and Vlachvei 2014, Kontogeorgos et al 2017). Profitability was found to be negatively correlated with debt ratio and firm size.

On the other hand, the relationship between profitability and asset structure was positive, it was found that profit increases as asset structure increases. This implies that an increase in asset structure to increase in production and revenue and thereby leads to increase in profitability. 
Discussions

This paper examines the effects of capital structure, asset structure, quick ratio, average payment period, firm size, and revenue growth rates on Vietnamese listed construction enterprises in the period of $2012-2018$. In correlation with previous domestic and foreign studies, this study also contributes to a better explanation of the factors affecting firm performance.

The represented variable is ROA. According to empirical research results, 3 of 6 independent variables included in the study affect ROA: capital structure, asset structure, firm size. Asset structure has a positive impact on performance. Vice versa, capital structure and firm size negatively impact on firm performance.

\section{Conclusion}

The results of this study show that it is always required large enough capital for long business cycles such as construction sector. The enterprises which have larger scale of business capital get the higher the profitability. Due to the ability to undertake large construction works, in the long run, and also easier to take advantage of opportunities business. In order to maintain a large scale of business capital, the enterprise cannot finance itself but then it needs to mobilize more capital from different sources. This will increase financial risk and affect the profitability of the business. Therefore, businesses need to be very careful in using the effects of financial leverage. This result can help construction enterprises explain the causes affecting the performance, thereby helping business administrators in selecting suitable business and production plans to increase profitability.

\section{References}

Addae, A. A., \& Nyarko-Baasi, M. (2013). Working Capital Management and Profitability: An empirical Investigation in an Emerging Market. Research Journal of Finance and Accounting, 4(15), 143-152.

Alshatti, A. S. (2015). The Effect of the Liquidity Management on Profitability in the Jordanian Commercial Banks. International Journal of Business and Management, 10(1), 62.

Bolek, M., \& Wilinski, W. (2012). The influence of liquidity on profitability of polish construction sector companies. e-Finanse, $8(1), 38$.

Dong, H., \& Su, J. T. (2010). The relationship between working capital management and profitability: a Vietnam case. International Research Journal Of Finance and Economics, Issue 49, PP 59-67.

Gill, A., Biger, N., \& Mathur, N. (2010). The relationship between working capital management and profitability: Evidence from the United States. Business and Economics Journal, 10(1), 1-9.

Khidmat, W. B., \& Rehman, M. U. Impact of liquidity \& solvency on profitability chemical sector of Pakistan. Economic Management Innovation, Vol. 6, Issue 3, 2014.

Kontogeorgos A., Pendaraki K. and F. Chatzitheodoridis, 2017. Economic crisis and firms' performance: empirical evidence for the Greek cheese industry. Revista Galega de Economia,26(1),73-82.

Lazaridis, I., \& Tryfonidis, D. (2006). Relationship between working capital management and profitability of listed companies in the Athens stock exchange. Journal of financial management and analysis, 19(1).

Michaelas, N., Chittenden, F., \& Poutziouris, P. (1999). Financial policy and capital structure choice in UK SMEs: Empirical evidence from company panel data. Small business economics, 12(2), 113-130.

Napompech, K. (2012). Effects of Working Capital Management on the Profitability of Thai Listed Firms. International Journal of Trade, Economics and Finance, 3(3), 227.

Notta O. and A. Vlachvei, 2014. The impact of Financial Crisis on firm performance in case of Greek food manufacturing firms. Procedia Economics and Finance, 14, 454-460.

Owolabi, S. A., \& Obida, S. S. (2012). Liquidity management and corporate profitability: Case study of selected manufacturing companies listed on the Nigerian stock exchange. Business Management Dynamics, 2(2), 10-25.

Punnose, E. M. (2008). A profitability analysis of business group firms vs. individual firms in the Indian electrical machine manufacturing industry. The Icfai Journal of Management Research, 7(1), 52-76.

Ramasamy, B., Ong, D., \& Yeung, M. C. (2005). Firm size, ownership and performance in the Malaysian palm oil industry. Asian Academy of Management Journal of Accounting and Finance, 1(1), 81-104.

Sivathaasan, N., Tharanika, R., Sinthuja, M., \& Hanitha, V. (2013). Factors determining profitability: a study of 
selected manufacturing companies listed on Colombo Stock Exchange in Sri Lanka.

Tu, T. T., \& Nguyen, U. T. Relationship between working capital management and profitability-empirical evidence from Vietnamese listed firms. The Vietnamese economic meeting.

Vijayakumar, A. (2011). Management of Corporate Liquidity and Profitability: An Emperical Study, International Journal of Marketing and Technology, Vol. 1, No. 6, pp. 168-169.

Yazdanfar, D. (2013). Profitability determinants among micro firms: evidence from Swedish data. International Journal of Managerial Finance, 9(2), 151-160. 